\title{
Sprawozdanie z obchodów Jubileuszu 50-lecia Zakładu Historii Wychowania UAM
}

DOI: $10.14746 /$ bhw.2017.37.15

W dniach 25-26 września 2017 r. na Wydziale Studiów Edukacyjnych Uniwersytetu im. Adama Mickiewicza w Poznaniu odbyły się uroczyste obchody Jubileuszu 50-lecia Zakładu Historii Wychowania UAM, zorganizowane pod hasłem „Wielkopolska i Wielkopolanie w dziejach edukacji”.

Obchody zainaugurowała prof. UAM dr hab. Justyna Gulczyńska, przewodnicząca Komitetu Organizacyjnego Jubileuszu, która powitawszy zebranych gości, przekazała głos Pełnomocnikowi Rektora UAM ds. rozwoju i zarządzania strategicznego, prof. zw. dr. hab. Zbyszkowi Melosikowi, który odczytał także listy gratulacyjne od JM Rektora Uniwersytetu im. Adama Mickiewicza w Poznaniu, prof. zw dra hab. Andrzeja Lesickiego oraz od prof. zw. dra hab. Bogusława Śliwerskiego, Przewodniczącego Komitetu Nauk Pedagogicznych Polskiej Akademii Nauk. Prof. Zbyszko Melosik podkreślił dynamiczny rozwój naukowy i organizacyjny Zakładu Historii Wychowania, a także jego otwartość na nowe idee badawcze.

Następnie głos zabrała Dziekan Wydziału Studiów Edukacyjnych UAM, prof. zw. dr hab. Agnieszka Cybal-Michalska, która przywitała gości w imieniu społeczności Wydziału Studiów Edukacyjnych, a w przemówieniu zauważyła ważną rolę historii wychowania w badaniach pedagogicznych, a także duże znaczenie badań, prowadzonych przez pracowników Zakładu Historii Wychowania UAM dla polskiej i światowej pedagogiki.

Kierownik Zakładu Historii Wychowania, prof. zw. dr hab. Wiesław Jamrożek po przywitaniu gości i podziękowaniu im za przybycie, przedstawił szczegółowo dzieje badań historyczno-pedagogicznych w poznańskim ośrodku naukowym, nawiązując do źródeł poznańskiej pedagogiki, sięgającej czasów Akademii Lubrańskiego oraz Kolegium Jezuickiego w Poznaniu. W swoim referacie omówił on także obszernie dzieje ogólnopolskich badań z zakresu historii wychowania, przywołując pierwszych teoretyków, jak np. Hugo Kołłątaja, Bronisława Trentowskiego czy Antoniego Karbowiaka, ale też osoby związane z Wszechnicą Piastowską, na której utworzono pierwszą w Polsce Katedrę Pedagogiki i Dydaktyki, gdzie pracowali m.in. Antoni Danysz, ks. Karol Mazurkiewicz czy Stanisław Tync. W dalszej części referatu prof. Wiesław Jamrożek omówił historię Zakładu Historii Wychowania, przedstawiając sylwetki i zainteresowania badawcze poszczególnych jego pracowników, włącznie z obecnymi. Aktualny skład osobowy Zakładu Historii Wychowania UAM natomiast wygląda następująco: Kierownik Zakładu, prof. zw. dr hab. Wiesław Jamrożek, prof. zw. dr hab. Dorota Żołądź-Strzelczyk, prof. UAM dr hab. Justyna Gulczyńska, prof. UAM dr hab. Edyta Głowacka-Sobiech, dr Krzysztof Ratajczak, dr Katarzyna Kabacińska-Łuczak, dr Mikołaj Brenk, dr Michał Nowicki oraz dr Konrad Nowak-Kluczyński.

Następnie, laudację wygłosił prof. zw. dr hab. Krzysztof Jakubiak z Uniwersytetu Gdańskiego, który przypomniał osoby pierwszych kierowników Zakładu, prof. Stanisława Michalskiego oraz prof. Jana Hellwiga. Prof. Krzysztof Jakubiak podkreślił szczegól- 
nie ogromny wkład wymienionych profesorów w rozwój naukowy wielu polskich historyków wychowania. Zwrócił on także uwagę na ewolucję zainteresowań badawczych pracowników Zakładu, zwłaszcza w obszarze społecznej historii wychowania. Wspomniał też o cyklicznie organizowanych przez pracowników Zakładu seminariach w Obrzycku, koncentrujących się na problematyce warsztatu badawczego współczesnego historyka wychowania, ale też mających duże znaczenie dla integracji środowiska polskich historyków wychowania. Następnie, zaproszeni goście z kilkunastu ośrodków uniwersyteckich złożyli na ręce Kierownika Zakładu gratulacje i życzenia. W poruszającym przemówieniu sylwetkę prof. Stanisława Michalskiego przybliżyła także jego małżonka, Janina Michalska.

Po krótkiej przerwie prof. zw. dr hab. Agnieszka Cybal-Michalska zainaugurowała część konferencyjną obchodów jubileuszowych, zatytułowaną „Myśl edukacyjna wczoraj i dziś", przygotowanym na tę okazję wykładem, koncentrującym się wokół zagadnienia: „nie teoria jest dobra, ale dobra teoria”. Referaty wygłosili także prof. zw. dr hab. Zbyszko Melosik, przedstawiając socjalizacyjną rolę myśli edukacyjnej, na podstawie doświadczeń szkół amerykańskich oraz prof. zw. dr hab. Kalina Bartnicka (Instytut Historii Nauki PAN), omawiając reformę uniwersytecką czasów Komisji Edukacji Narodowej.

Po tych referatach nastąpiła prezentacja osiągnięć Zakładu Historii Wychowania, przygotowana przez dr. Mikołaja Brenka oraz dr. Konrada Nowak-Kluczyńskiego, a także prezentacja książki, wydanej z okazji Jubileuszu Zakładu, pt. Wielkopolska i Wielkopolanie $w$ dziejach polskiej edukacji, pod redakcją naukową prof. UAM dr hab. Edyty Głowackiej-Sobiech i dr Katarzyny Kabacińskiej-Łuczak. Uroczystości towarzyszyła także wystawa publikacji pracowników Zakładu Historii Wychowania UAM.

Zwieńczeniem pierwszego dnia obchodów Jubileuszu było odsłonięcie pamiątkowej tablicy, poświęconej założycielowi Zakładu, prof. dr. hab. Stanisławowi Michalskiemu, po czym nastąpił koncert Chóru Kameralnego UAM pod batutą prof. Krzysztofa Szydzisza oraz uroczysty bankiet.

Drugiego dnia obchodów jubileuszowych miały miejsce „Warsztaty tumskie”, przygotowane i prowadzone przez dr. Michała Nowickiego i dr. Krzysztofa Ratajczaka. Zaproszeni goście mieli okazję zwiedzić miejsca związane z początkami miasta Poznania i jego szkolnictwem, tj. szkołą katedralną oraz Akademią Lubrańskiego, poznać zasób Archiwum Archidiecezjalnego w Poznaniu, gdzie w Pracowni Inkunabułów prezentowane były materiały archiwalne i biblioteczne z okresu średniowiecza i epoki nowożytnej, a na zakończenie zwiedzić Interaktywne Centrum Historii Ostrowa Tumskiego (tzw. Bramę Poznania).

Tego dnia też odbyło się posiedzenie członków Prezydium Komitetu Nauk Pedagogicznych Polskiej Akademii Nauk.

Michat Nowicki

Wydział Studiów Edukacyjnych Uniwersytet im. Adama Mickiewicza w Poznaniu 